Visualizing Objects, Places, and Spaces: A Digital Project Handbook

\title{
MAPA: Digital Atlas of Ukraine
}

\section{Serhii Plokhii, Kostyantyn Bondarenko}

Published on: Apr 28, 2021

License: Creative Commons Attribution-NonCommercial-NoDerivatives 4.0 International License (CC-BY-NC-ND 4.0). 


\section{Team}

Faculty Project Director: Prof. Serhii Plokhii, Director, Ukrainian Research Institute, Harvard University

Project Manager: Kostyantyn Bondarenko, IT Professional, Ukrainian Research Institute, Harvard University

A complete list of MAPA program members and associates is available here.

\section{Project URL}

https://gis.huri.harvard.edu

\section{Project Abstract}

The MAPA: Digital Atlas of Ukraine program, undertaken by the Ukrainian Research Institute at Harvard University and its partners, brings the latest innovations of information technology to studies of modern Ukrainian history and contemporary political geography. We conduct our own studies and encourage scholars and students within the Harvard community and beyond to use Geographic Information Systems (GIS) for illustrating and explaining economic, historical, political, and social transformations within Ukraine using spatial and temporal analysis.

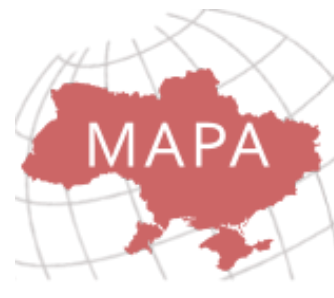

\section{Digital Atlas of U K R A I N E}

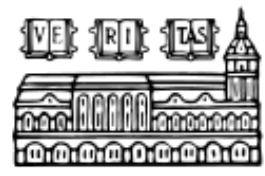

\section{Time Needed}

When did you begin this project? When did you complete this project?

Time Span: November 1, 2010 - present

Length: $10+$ years 


\section{Outcomes}

What is the outcome of the project?

A website, project fellowship, regular presentations at conferences, and resources used by researchers and instructors in the US and abroad.

Prof. Serhii Plokhii (Harvard University) used the Great Famine project maps in his course "Frontiers of Europe: Ukraine since 1500". Students were doing assignments based on the data and maps. Prof. Plokhi integrated data from the Great Famine project in his books "The Gates of Europe: A History of Ukraine" and "Chernobyl: History of the Tragedy." His article on the Leninopad (Leninfall) was written on the basis of the data and maps in the Revolution of Dignity project.

Prof. Thomas Mueller's (California University of Pennsylvania) students examine the Revolution of Dignity. project maps to understand the issues of language and how its spatial distribution can be impacted by history, economics, and politics. Then students take that knowledge and examine the transfer of Ukrainian Orthodox parishes attempting to make connections between culture. Project maps allow them to examine these issues temporally as well. In some semesters, students also examine the Great Famine project maps and research the possible causes of the Great Famine. The MAPA program allows students to become researchers to critically question and think about these concepts.

Prof. Viktoria Sereda (National Academy of Sciences of Ukraine) uses MAPA in both problem-oriented and research methodology training courses. In her course "Historical Memory in the Post-Communist Space: Ukraine and Its Neighbors Since the 1990s," she uses the History and Identity. module to generate discussions on how historical memory functions in the time of political transformations or military conflict. Her students explore how new and reemerging contested historical memories have redefined cultural spaces of Ukrainian cities and citizens' imaginary. In her "Urban Sociology" course she illustrates to her class symbolic markers of urban space with maps presenting attitudes to decommunization in comparison to the number of dismantled monuments in each region. In both cases she employs MAPA to exemplify certain social phenomena, which can be found all over the globe. In "Migration and belonging. Ukraine in local perspective after 1991" she focuses on spatial representations that help her students to understand disputed regions better and to visualize flows of internally displaced people and society's reaction on them. 
MAPA program outcomes are regularly presented at international conferences (ASN, ASEEES).

\section{Website}

The MAPA: Digital Atlas of Ukraine program website consists of the Historical and Contemporary Atlases. Each atlas is divided into projects.

The Historical Atlas comprises the 'Great Ukrainian Famine of 1932-1933' project, the 'Rus' Genealogy' project, and the 'Historic Podillya' project.

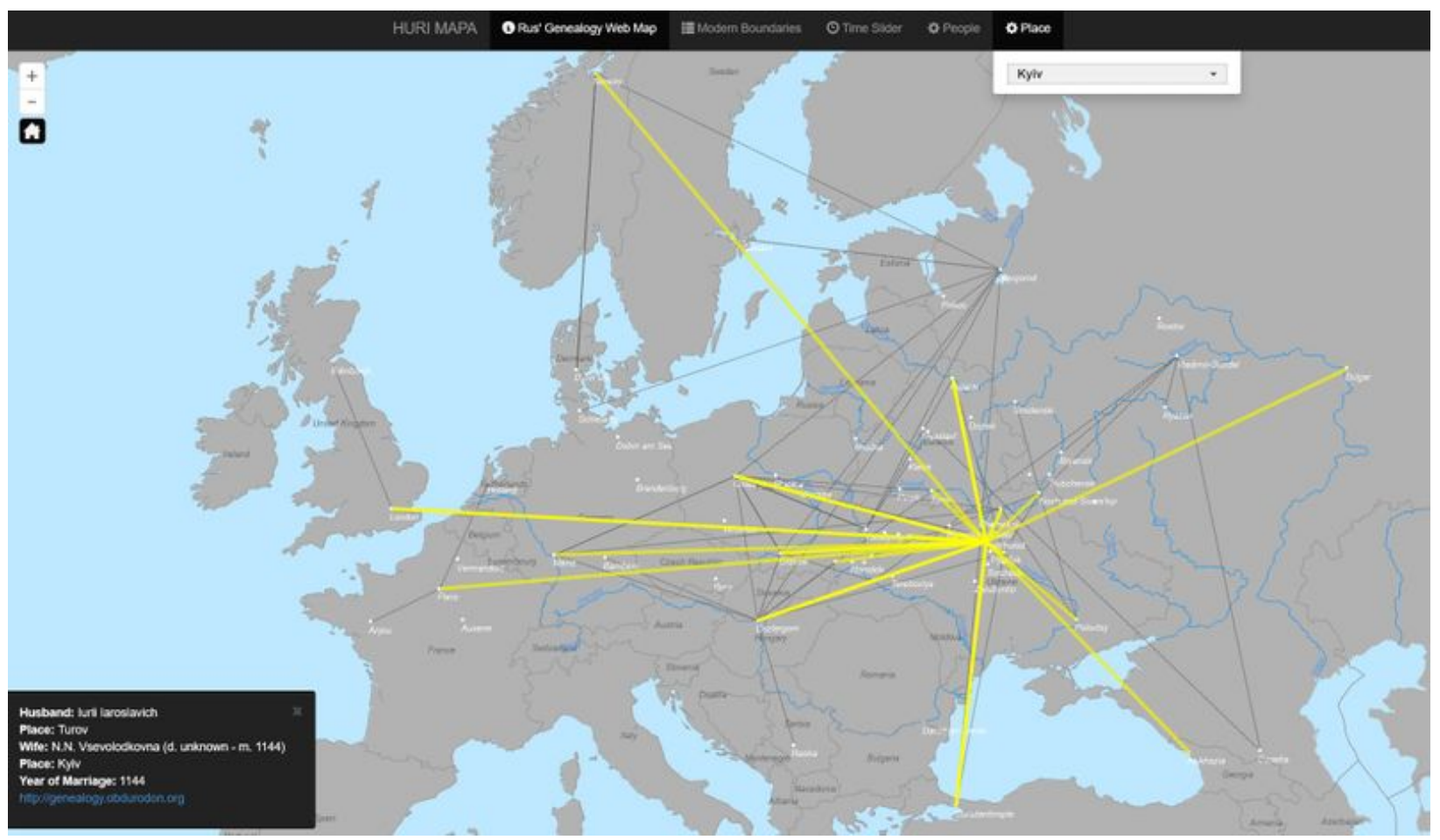

Rus' Genealogy web map showing lines of marital connections.

The Contemporary Atlas comprises the 'Revolution of Dignity' project and the 'Ukraine and Russia: Together or Apart?' project.

'Revolution of Dignity', being the largest project, is further subdivided into modules. It comprises the 'Donbas and Crimea In Focus' module, the 'Religious Revolution' module, the 'History and Identity' module, the 'Language' module, the 'Revolution on Granite' module, and the 'Statistics' module. 


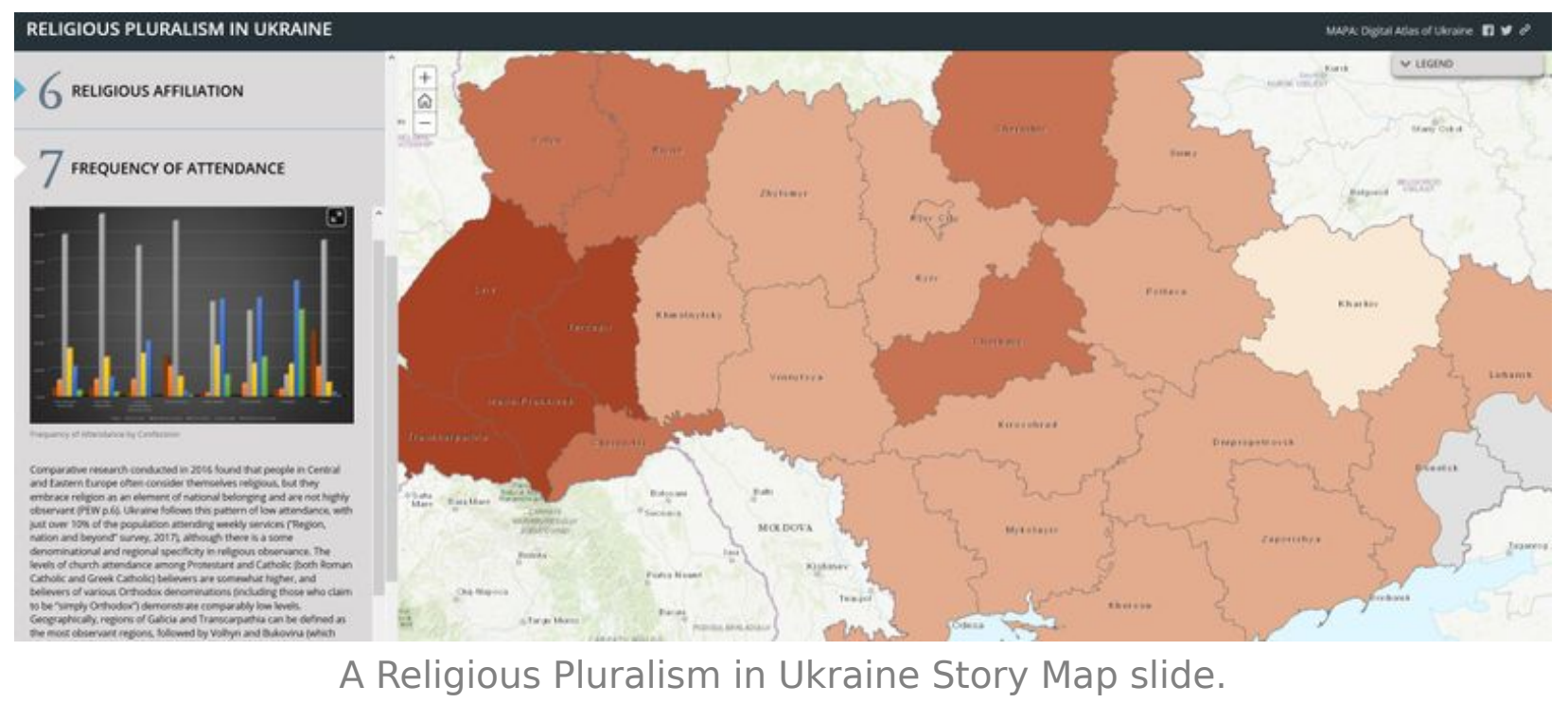

The website contains different types of maps within each project or module. The map types are interactive web maps (layers) withing web map applications (Great Ukrainian Famine, Revolution of Dignity), interactive timeline maps (Rus' Genealogy, Transfer of Ukrainian Orthodox Parishes, Historic Podillya), story maps (Great Ukrainian Famine, Religious Pluralism in Ukraine), map galleries (Great Ukrainian Famine).

\section{Research, Publications and Teaching}

The MAPA program website has a research analysis section that includes articles based on the program data and maps. These are 'Mapping the Great Famine', 'Mapping_Marriage: Kyivan Rus' in Europe', and 'Leninfall'.

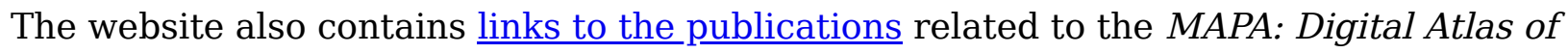
Ukraine program.

The Great Famine maps were cited in the paper "Demography of a Man-Made Human Catastrophe: the Case of Massive Famine in Ukraine 1932-1933." O.P. Rudnytskyi, Nataliia Levchuk, Oleh Wolowyna, Pavlo Shevchuk, and A.B. Kovbasiuk. 2015. ( "Demography of a Man-Made Human Catastrophe: the Case of Massive Famine in Ukraine 1932-1933." Canadian Studies in Population, 42, 1-2, Pp. 53-80.) 
The Revolution on Granite maps were cited in the paper "Mapping Support for a Revolution: Evidence from Ukraine." (Olena Nikolayenko. 2020. "Mapping Support for a Revolution: Evidence from Ukraine.” International Journal of Sociology, Pp. 1-31.)

\section{Resources}

What tools, resources, programs, or equipment did you use for this project?

- Harvard Center for Geographic Analysis

- GIS software and online portal:

- ESRI ArcMap

- $\underline{\text { ArcGIS Online }}$

\section{Funding}

Please describe any costs incurred for this project, and (if relevant) how you secured funding for these costs.

The project is funded by Ukrainian Research Institute at Harvard University. Labor costs are covered by the Institute's endowment funds. ArcGIS licensing is covered by Harvard Center for Geographic Analysis.

\section{Workflow}

Please give an overview of the workflow or process you followed to execute this project, including time estimates where possible.

The MAPA: Digital Atlas of Ukraine program has been in development by the Ukrainian Research Institute at Harvard University since 2010.

It went through many stages. It has several distinct projects and modules-each project and module took several months to finish.

The two members of the MAPA team, Faculty Project Director Prof. Serhii Plokhii and Project Manager Kostyantyn Bondarenko, are regular employees at the Ukrainian Research Institute at Harvard University. They work on the MAPA program in addition to their other responsibilities at the Institute. 
Each year the MAPA program has a visiting fellow working on a specific project/module full-time for one academic year.

\section{Challenges \& Opportunities}

What, if anything, changed between beginning your project and its current/final form?

The project has changed as GIS and web technologies have developed over time. At the beginning, the focus was on traditional and online maps, but with time the focus shifted primarily to online web map applications. Using ESRI's ArcGIS Online platform, ArcGIS Web AppBuilder, and ArcGIS Configurable Apps templates helped us create interactive web map applications with built-in analytical tools.

Is there anything specific you wish you had known when beginning your project that might help other people to know?

Planning is the hardest thing to do, especially when it is a brand new project. We wished we had a more comprehensive strategy for the project development but it was not possible really as we had no idea where the project might lead us. Our advice: try to plan by looking at similar projects but be ready to change directions and adapt.

\section{Next Steps}

Do you have any plans to follow up on this project or work on something similar in the future?

Yes, we are working on a new project mapping and analyzing data related to the Chernobyl/Chornobyl disaster.

\section{Publications \& Presentations}

- $\underline{\text { Presentations }}$

- List of Publications 